\title{
EVALUASI PROGRAM BANTUAN BEASISWA SANTRI BERPRESTASI (PBSB) DI PESANTREN
}

\section{EVALUATION OF SCHOLARSHIP PROGRAM FOR SANTRI OF HIGH ACHIEVEMENT (PBSB) AT PESANTREN}

\author{
Iyoh Mastiyah \\ Puslitbang Pendidikan Agama dan Keagamaan \\ Balitbang dan Diklat lementerian Agama RI \\ JL. MH Thamrin No. 06 Jakarta Pusat \\ Mastiyah9@gmail.com
}

Naskah diteraima 17 Januari 2017, direvisi 25 Februari 2017, disetujui 20 Maret 2017

\begin{abstract}
This article aims at finding out the implementation of PBSB by using an evaluation study model and quantitative method. The evaluation model used is CIPP (Input, process, output) model. Of the findings in the field shows the relevance between the implementation of $P B S B$ and PBSB idealized goal, namely from the input aspect, the affirmation policy is very visible from the program, i.e. providing access to scholarship education for poor families in which they mostly take public majors rather than religion. Of the process aspect, this study finds that santri successfully completes the study timely, especially santri from poor family background. Of the output/ product aspect, the santri's academic achievement derived from the poor family succeeds in obtaining high average score of 3.32. However, their devotion as pesantren empowerment has not fully grown, where the activity percentage of PBSB alumni at pesantren is still limited to administrative management, teaching and development of life skill.
\end{abstract}

Keywords: Evaluation, PBSB, Pesantren

\begin{abstract}
Abstrak
Artikel ini bertujuan untuk mengetahui implementasi PBSB dengan menggunakan model penelitian evalusi dan metode kuantitatif. Model evaluasi yang digunakan adalah model CIPP (Input, proses, output). Dari temuan di lapangan menunjukkan adanya relevansi antara implementasi PBSB dengan tujuan yang diidealisasikan PBSB, yaitu dari aspek input, kebijakan afirmasi sangat nampak dari program ini, yakni memberikan akses pendidikan beasiswa bagi keluarga tidak mampu dimana mereka lebih banyak yang mengambil jurusan umum dari pada agama. Dari aspek proses, studi ini menemukan bahwa santri berhasil menyelesaikan studi tepat waktu, terutama santri berlatarbelakang keluarga tidak mampu. Dari aspek output/produk, prestasi akademik santri yang berasal dari keluarga tidak mampu berhasil memperoleh rerata nilai cukup tinggi 3,32. Namun, pengabdian mereka sebagai pemberdaya pesantren belum sepenuhnya tumbuh, dimana aktivitas alumni PBSB di pesantren masih terbatas persentasenya pada pengelolaan administrasi, pengajaran dan pengembangan life skill.
\end{abstract}

Kata Kunci: Evaluasi, PBSB, Pesantren 


\section{PENDAHULUAN}

Peningkatan akses pendidikan yang berkualitas kini sedang menjadi isu krusial di kalangan pesantren. Label pesantren sebagai pendidikan keagamaan yang berorientasi pada tafaqquh fiddin kini bertransformasi seiring perubahan sosial. Tak pelak, kondisi ini direspon oleh Kementerian Agama untuk mengakselerasi penguatan keilmuan pesantren melalui anak-anak didiknya yang mengenyam pendidikan madrasah. Tak tanggung-tanggung, Kementerian Agama meluncurkan program Beasiswa Santri Berprestasi (PBSB) dimana siswa lulusan madrasah di pesantren diberi kesempatan untuk melanjutkan studi Perguruan Tinggi Negeri prestisius, seperti UIN Syarif Hidayatullah Jakarta, UIN Sunan Gunung Djati Bandung, UIN Wali Songo semarang, UIN Sunan Kalijaga Yogyakarta, UIN Sunan Ampel Surabaya, UIN Maulana Malik Ibrahim Malang, Universitas Pendidikan Indonesia, Institut Teiknologi Bandung, Institut Pertanian Bogor, Universitas Indonesia Jakarta, Institut teknologi Surabaya, Universitas Airlangga, Universitas Gadjah Mada, Universitas Mataram dan Universitas Islam Malang dan STAINU Jakarta. ${ }^{1}$

PBSB ini telah berjalan sejak tahun 2005 hingga sekarang. Jumlah santri yang mengikuti program ini sebanyak 3.330 orang (tahun 2015), yang berasal dari 782 pesantren. Jjumlah santri yang telah menyelesaikan studinya sampai Desember 2014 mencapai 1.380 santri. $^{2}$ Data ini

${ }^{1}$ Petunjuk Teknis Pengelolaan Program Beasiswa Santri Berprestasi (PBSB) Tahun 2015, Direktorat Pendidikan Diniyah dan Pondok Ponpes Ditjen Pendidikan Islam, Kementerian Agama RI. h. 4

${ }^{2}$ Petunjuk Teknis Pengelolaan Program Beasiswa Santri Berprestasi, h.5 menunjukkan bahwa mobilitas intelektual santri mengalami perkembangan. Namun, tampak adanya gap antara tujuan PBSB dengan hasil yang dicapai, karena alumni program baru bergerak mobilitas intelektualnya, sedangkan pemberdayaan sosial dan penguatan kelembagaan pesantren tidak begitu nampak. Indikasinya adalah bahwa alumni program ini sangat sedikit yang kembali ke pesantren untuk memperkuat kelembagaan pesantren melalui penerapan sains dan teknologi. Mereka cenderung memilih bekerja di luar pesantren atau melanjutkan ke jenjang pendidikan lebih tinggi.

Keberpihakan program PBSB ini kepada santri MA/Mu'adalah semakin membaik. Pada awal program ini diluncurkan masih ada kuota SMA dan SMK yang notabene juga memiliki kesempatan memperoleh beasiswa dari Kementerian lain akan tetapi diperbolehkan juga memperoleh kesempatanbeasiswa diKementerian Agama. Oleh karena itu, Petunjuk Teknis PBSB 2016 "sudah sangat tepat" mensyaratkan santri pesantren khusus untuk MA dan Mu'adalah. Hal ini menunjukkan bahwa kebijakan afirmasi ditujukan kepada santri yang berpendidikan madrasah/mauadalah yang selama ini kalah bersaing dengan SMA. ${ }^{3}$

Dari pelaksanaan PBSB selama 5 tahun, ada dugaan tujuan yang ingin dicapai dari program $\mathrm{PBSB}$ ini tidak sesuai dengan hasil yang diperoleh. Alumni PBSB yang diharapkan mampu menjadi aktor penting dalam penguat kelembagaan pesantren melalui penerapan sains dan teknologi dan

${ }^{3}$ Taufik M Tata, 2016. PBSB dari Masa ke Masa, Makalah disampaikan dalam Pra Seminar Evaluasi Program Beasiswa Santri Berprestasi, di Take's Mansion Hotel Jakarta, 29 September 
pemberdayan sosial masyarakat belum terelialisasi sesuai harapan. Faktor yang mendorong hal tersebut dapat bermula dari proses implementasi PBSB yang tidak optimal.

Oleh karena itu pertanyaan dalam penelitian ini adalah sejauhmana implementasi program PBSB dilihat dari sisi input, proses, output dan out come pendidikan PBSB ? Adapun tujuan penelitian ini untuk memperoleh data dan informasi terkait implementasi PBSB dilihat dari kerangka, input, proses, produk dan outcome dari penyelenggaraan pendidikan PBSB. Sedangkan manfaat yang diperoleh dari penelitian ini untuk memberikan saran dan masukan bagi pimpinan Kementerian Agama tentang langkah-langkah konkrit dan komprehensif untuk membuat kebijakan tentang pelaksanaan bantuan program beasiswa santri berprestasi (PBSB) di masa akan datang khususnya pemberdayaan alumni PBSB.

\section{Kerangka Konseptual}

\section{Program Beasiswa Santri}

Program beasiswa santri berprestasi disingkat PBSB adalah sebuah program afirmatif perluasan akses santri untuk melanjutkan studi melalui suatu program yang terintegrasi mulai dari proses kerjasama, pengelolaan, sistem seleksi khusus bagi santri serta pemberian bantuan pembiayaan yang diperlukan bagi santri yang memenuhi syarat, sampai pembinaan masa studi dan pengabdian pasca lulus. ${ }^{4}$

${ }^{4}$ Buku "Petunjuk Teknis Pengelolaan Program Beasiswa Santri Berprestasi (PBSB) tahun 2015, Direktorat Pendidikan Diniyah dan Pondok Pesantren Ditjen Pendidikan Islam, Kementerian Agama RI. h.4
Misi diselenggakannya PBSB agar para santri setelah menyelesaikan studinya di perguruan tinggi dapat memperkuat pemberdayaan dan pengembangan ponpes, terutama di bidang sains dan teknologi di samping islamic studies, sehingga potensi yang ada di lingkungan pesantren dapat diberdayakan dengan baik, yang pada gilirannya pesantren akan tetap eksis sebagai lembaga pendidikan dan pengembangan masyarakat (community development). ${ }^{5}$

Tujuan program beasiswa santri berprestasi sebagai pemberdayaan sosial bagi santri melalui upaya memperluas akses bagi santri berprestasi yang memiliki kematangan pribadi, kemampuan penalaran, dan prestasi untuk memperoleh pendidikan tinggi, melalui tindakan afirmatif dalam seleksi masuk perguruan tinggi. ${ }^{6}$

Program ini juga merupakan turunan dari program RPJMN terkait perluasan akses pendidikan khususnya bagi masyarakat Indonesia yang memiliki prestasi akademik akan tetapi memiliki keterbatasan biaya pendidikan untuk memperoleh jenjang pendidikan tinggi.?

PBSBsebagaiupayapemberdayaansosial bagi pesantren melalui upaya peningkatan kualitas SDM pondok pesantren di bidang sains, teknologi serta sosial kemasyarakatan agar dapat mengoptimalkan peran

${ }^{5} \mathrm{Buku}$ "Petunjuk Teknis Pengelolaan Program Beasiswa Santri Berprestasi (PBSB) tahun 2015, Direktorat Pendidikan Diniyah dan Pondok Pesantren Ditjen Pendidikan Islam, Kementerian Agama RI. h.5

${ }^{6} \mathrm{Buku}$ "Petunjuk Teknis Pengelolaan Program Beasiswa Santri Berprestasi (PBSB) tahun 2015, Direktorat Pendidikan Diniyah dan Pondok Pesantren Ditjen Pendidikan Islam, Kementerian Agama RI. h.5

${ }^{7}$ RPJMN tahun tahun 2015-2019 
pembangunan di masa mendatang. Santri diharapkan mampu mengimplementasikan keilmuan di perguruan tinggi khususnya penerapan teknologi dan informasi melalui program pemberdayaan pesantren setelah menempuh studi.

Atas dasar hal tersebut maka program PBSB lahir untuk berkontribusi bagi peningkatan kualitas SDM pesantren dan peningkatan akses kesempatan memperoleh pendidikan jenjang tinggi bagi santri. Pada masa akan datang, pesantren diharapkan memiliki daya saing terhadap perubahan zaman dengan mengakomodasi penerapan teknologi dan informasi tanpa menghilangkan jati diri pesantren.

\section{Pondok Pesantren}

Menurut Arifin dalam Mujamil Qomar, pesantren adalah suatu lembaga Pndidikan Agama Islam yang tumbuh serta diakui oleh masyarakat sekitar, dengan sistem asrama (komplek), dimana santri menerima pendidikan agama melaui system pengajian atau madrasah yang sepenuhnya berada di bawah kedaulanan leadership seseorang atau beberapa orang kyai. ${ }^{8}$ Sementara menurut Yasmadi "pesantren" merupakan lembaga Pendidikan dengan bentuk khas sebagai tempat dimana proses pengembangan keilmuan, moral dan keterampilan para santri menjadi tujuan utamanya. Istilah pesantren berasal dari kata "santri" dengan awalan "pe" dan akhiran "an" yang berarti tempat tinggal santri. Sebagai lembaga Pendidika Islam, pesantren memiliki lima elemen yaitu pondok tempat menginap,

\footnotetext{
${ }^{8}$ Mujamil Qomar,TT. Pesantren,dari Transformasi Metodologi Menuju Demoktratisasai Institusi. Jakarta, Erlangga, H. 1-3
}

santri, masjid, pengajian kitab klasis dan kyai. ${ }^{9}$

Sementara dalam pedoman PBSB dijelaskan bahwa pesantren yang dimaksud dalam hal ini adalah lembaga pendidikan keagamaan Islam berbasis masyarakat yang menyelenggarakan pendidikan diniyah (pendidikan keagamaan Islam yang diselenggarakan pada semua jalur dan jenjang pendidikan) atau secara terpadu dengan jenis pendidikan lainnya. Dalam konteks pembangunan berkelanjutan, pesantren sebagai satuan pendidikan yang ada di masyarakat mempunyai kontribusi penting bagi penyediaan sumber daya manusia, tidak terbatas pada penguasaan kitab (ilmu agama) tetapi juga mempunyai kompetensi sosial dan pemahaman informasi teknologi. ${ }^{10}$

\section{Evaluasi}

Evaluasi didefinisikan sebagai proses pencarian, pengumpulan dan pengambilan data (informasi) yang diperlukan untuk memberikan pertimbangan apakah program yang sedang berjalan perlu diperbaiki, dihentikan atau diteruskan. ${ }^{11}$ Jaedun Amat menyatakan bahwa evaluasi dapat digunakan sebagai penentu kebijakan. Kebijakan akan tepat apabila data yang digunakan sebagai pertimbangan tersebut benar, akurat, dan lengkap, karena evaluasi

${ }^{9}$ Yasmadi. 2005. Modernisasi Pesantren, Kritik Nurkholis Madjid terhadap Pendidikan Islam Trdisional, ,Jkarta,Ciputat Press, h. 63.

${ }^{10} \mathrm{Buku}$ "Petunjuk Teknis Pengelolaan Program Beasiswa Santri Berprestasi (PBSB) tahun 2015, Direktorat Pendidikan Diniyah dan Pondok Pesantren Ditjen Pendidikan Islam, Kementerian Agama RI. h.3

${ }^{11}$ W. James Popham. 1981. Modern Educational Evaluation, New Jersey: Prenctice Hall Inc, h. 7. 
dapat menentukan ketercapaian sebuah program..$^{12}$

Program PBSB merupakan suatu rangkaian kegiatan sebagai bentuk implementasi dari suatu kebijakan pemerataan akses pendidikan bagi santri, oleh karena itu maka evaluasi program PBSB pada dasarnya merupakan kegiatan evaluasi terhadap implementasi dari suatu kebijakan.

Selain itu menurut Bigman bahwa evaluasi program, yaitu: (1) Untuk menemukan apakah tujuan dapat dicapai, dan seberapa jauh dapat dicapai. (2) Untuk menemukan prinsip yang melandasi keberhasilan program. (3) Untuk melakukan eksperimen-eksperimen dengan teknikteknik tertentu guna meningkatkan efektifitas. (4) Untuk meletakkan dasar guna melakukan penelitian lanjut atas dasar keberhasilan alternative teknik yang digunakan. (5) Untuk merumuskan kembali cara yang akan digunakan dalam mencapai tujuan, dan bahkan merumuskan kembali sub tujuan sesuai dengan temuan penelitian. $^{13}$

Evaluasi merupakan salah satu jenis obyek dari penelitian evaluasi (Evalution Research). Model penelitian evaluasi yang dipakai dalam penelitian ini adalah model CIPP yang dikembangkan Stufflebeam dkk. Model evaluasi model CIPP terdiri empat komponen, yaitu : konteks, input, proces, dan

${ }^{12}$ Jaedun Amat. 2010. Metode Penelitian Evaluasi Program, Makalah Disampaikan Pada Kegiatan Pelatihan Metode Penelitian Evaluasi Kebijakan dan Evaluasi Program Pendidikan

${ }^{13}$ Leonard Rutman. 1984. Evaluation Research Methodology, New Delhi; Sege Publication India PVT. Ltd, 2 ed, h. 123 produk. ${ }^{14}$ Namun dalam penelitian ini yang akan digunakan hanya pada tiga komponen yaitu input, proses dan produk/output. Selain itu untuk melihat dampaknya dilihat juga dimensi outcome.

Keunggulan model ini adalah memberikan suatu kajianyang komprehensif dari suatu fenomena sosial yang sedang diamati. Model CIPP berorientasi pada pengambilan keputusan (decision oriented). Orientasi mendasar pada semua penelitian evaluasi adalah manfaat. Manfaat yang dimaksud adalah menyediakan informasi terkait pelaksanaan PBSB untuk mengambil kebijakan dalam rangka peningkatan kualitas pelaksanaan PBSB dimasa akan datang.

Dengan demikian evaluasi PBSB yang digunakan dalam studi ini adalah untuk menilai atau mengukur implementasi PBSB dari aspek input, proses, produk/output serta outcome. Input adalah hal yang berhubungan dengan sumber-sumber yang tersedia yang mengarahkan strategi program dan menspesifikasi rancangan prosedural yang meliputi mekanisme rekruitmen santri PBSB dan kebutuhan ponpes terhadap PBSB. Proses adalah sesuatu yang berhubungan dengan prosedur kegiatan implementasi kebijakan atau keputusan yang meliputi aktivitas proses monitoring santri PBSB, pembinaan santri $\mathrm{PBSB}$, evaluasi $\mathrm{PBSB}$ serta mengidentifikasi masalah dan kendala. Produk adalah sesutu yang berhubungan dengan keberhasilan pencapaian tujuan PBSB, yang meliputi prestasi, sebaran alumni, pendayagunaan alumni, sedangkan outcome adalah sesuatu dampak atau manfaat

${ }^{14}$ W. James Popham. 1974. Educational Evaluation, New Jersey; Prentice-Hal Inc, h. 34. 
alumni bagi penguatan kelembagaan ponpes yang meliputi pengembangan mutu ponpes.

Adapun pemberdayaan sosial yang dirumuskan dalam studi ini kemampuan untuk melakukan sesuatu atau untuk bertindak yang berupa akal, ikhtiar atau upaya atau proses transmisi dari keadaan tidak berdaya menuju keadaan yang lebih baik. Semuanya ini diukur dengan indikator pemberdayaan yaitu: akses, partisipasi, kontrol (pengendalian dan tata kelola) dan manfaat. Dalam konteks pendidikan, maka pemberdayaan difungsikan untuk menggerakan semua potensi sumberdaya yang ada di pesantren, sehingga menghasilkan kualitas pendidikan dan keberdayaan masyarakat sekitar. Dimensi indikator pemberdayaaan pendidikan pesantren adalah meliputi SDM, sarana prasarana pendidikan, metode, kurikulum, interaksi sosial internal dan eksternal.

\section{METODOLOGI PENELITIAN}

Model penelitian evaluasi yang dipakai dalam studi ini adalah model CIPP yang dikembangkan Stufflebeam, yang terdiri dari empat komponen, yaitu: konteks, input, proses, dan produk. ${ }^{15}$ Keunggulan model ini adalah memberikan suatu kajian yang komprehensif dari suatu fenomena sosial yang sedang diamati. Model CIPP berorientasi pada pengambilan keputusan (decision oriented).

Studi ini dilaksanakan di 11 provinsi, yaitu Aceh, Banten, Jawa Barat, Jawa Tengah, Jakarta Timur, DI Yogyakarta, Lampung, Sumatera Barat, Sumatera Utara,

${ }^{15}$ W. James Popham. 1974. Educational Evaluation New Jersey, Prentice-Hal Inc, h. 34.
Kalimantan Selatan dan Sulawesi Selatan. Populasi yang digunakan dalam studi ini adalah seluruh pesantren yang memiliki alumni PBSB dengan unit analisis yaitu lembaga pesantren. Berdasarkan data Direktorat PD Pontren, pada tahun 2014 terdapat 782 lembaga pesantren dengan jumlah alumni sebanyak 1437 orang. ${ }^{16}$ Namun pesantren yang memiliki alumni PBSB sejumlah 427 lembaga. Karena itu, jumlah sampel berdasarkan rumus slovin dengan margin error sebesar 0,10\% dan tingkat kepercayaan 95\%. diperoleh besaran sampel sebanyak 81 lembaga dari 427 lembaga. Selanjutnya untuk menentukan jumlah lembaga pada masingmasing wilayah sasaran studi ditentukan secara proporsional. Namun untuk daerah tertentu yang jumlah pesantrennya sedikit, semua pesantren dijadikan sebagai sampel, sehingga jumlah sampel meningkat menjadi 103 sampel lembaga. Sedangkan responden yang dijadikan sasarannya adalah Kyai dan alumni PBSB, dengan jumlah sesuai jumlah lembaga psantren, yaitu kyai sebanyak 103 orang dan alumni 234 orang, dari 103 lembaga.

Tehnik pengumpuan data dilakukan dengan cara pengisian kuesioner dalam bentuk angket/pilihan, dimana masingmasing responden (kyai dan alumni) diminta mengisi atau memilih jawaban yang telah disediakan dalam bentuk pilihan a,b,c,d atau e dan steterusnya. Selanjutnya data hasil penelitian dianalisis dengan menggunakan tehnik analisis statistik deskriptif.

${ }^{16}$ Lihat Data Hasil Update Direktorat PD Pontren Kementerian Agama tahun 2014 


\section{HASIL DAN PEMBAHASAN}

\section{Tingkat Relevansi Input Pendidikan}

Komponen input adalah sesuatu yang berhubungan dengan sumber-sumber yang mengarahkan strategi program dan menspesifikasi rancangan serta menetukan prosedural implementasi PBSB meliputi, mekanisme rekruitmen santri PBSB dan latar belakang santri. Indikator dimensi input terdiri dari; latar belakang santri PBSB, terlihat distribusi jenis kelamin antara laki-laki dan perempuan dalam sampel penelitian cukup berimbang, yaitu santri alumni PBSB laki-laki 49\% dan perempuan $51 \%$ yang berarti santri laki-laki dan perempuan mempunyai kesempatan yang sama untuk mendapatkan beasiswa PBSB.

Sistem seleksi terbuka yang dinyatakan dalam Petunjuk Teknis 2015 dan 2016 memberikan kesempatan dan peluang yang sama bagi santri laki-laki atau perempuan untuk memperoleh jenjang pendidikan tinggi. Sementara latar belakang orang tua santri juga cukup beragam. Dalam penelitian ini, pendidikan orang tua santri mayoritas berpendidikan SMU/MA (32,5\%) dan S1 $(26,1 \%)$. Sedangkan orang tua santri yang berpendidikan SD/MI tercatat ada (24,8\%) dan SMP/MTs (12,8\%). Ini menunjukan bahwa santri yang mendaftar menjadi peserta PBSB dari kalangan orang tua yang rata-rata berpendidikan menengah ke bawah.

Karakteristik latar belakang orang tua santri dari keluarga petani terhitung ada $29 \%$, buruh ada $8 \%$, PNS ada $24 \%$ dan sisanya adalah wiraswasta ada 39\%. Adapun latar belakang santri yang ikut program PBSB berdasarkan pandangan Kyai adalah ada 20.4\% Kyai yang menyatakan semua santri yang ikut PBSB berasal dari keluarga tidak mampu, ada 30.1\% kyai menyatakan bahwa sebagian besar keluarga santri PBSB tidak mampu, ada 29.1\% Kyai berpandangan bahwa antara yang mampu dan tidak mampu seimbang. Sisanya ada $20.3 \%$ kyai berpandangan bahwa program PBSB berasal dari santri yang mampu saja. Dari hasil pandangan tersebut dapat disimpulkan bahwa santri yang ikut program PBSB sebagian besar adalah keluarga tidak mampu walaupun ada sebagian kecil lainnya yang berasal dari keluarga mampu.

Temuan penelitian ini cukup menarik untuk dikaji. Program PBSB seperti halnya Progam Beasiswa Bidikmisi termasuk kelompok beasiswa afirmasi. Dalam paparan Bappenas, program beasiswa afirmasi lebih diutamakan bagi mereka yang berasal dari keluarga tidak mampu. Tujuan utama program beasiswa afirmasi adalah meningkatkan akses dan kesempatan belajar di perguruan tinggi bagi peserta didik yang tidak mampu secara ekonomi dan berpotensi akademik baik"17.

Dalam kontek pembangunan berkelanjutan, keberpihakan pada masyarakat tidak mampu mempunyai dua tujuan yaitu memperkecil gap disparitas kesempatan keluarga mampu dan tidak mampu dalam menyekolahkan anakanaknya ke perguruan tinggi dan kedua dalam jangka panjang dapat memutus rantai kemiskinan. Data Bappenas yang bersumber

${ }^{17}$ Bappenas, 2016, Peningkatan Akses Pendidikan Tinggi Melalui Program-Program Afirmasi Direktorat Pendidikan dan Agama Kementerian PPN/ BAPPENAS, 2016, Disampaikan dalam Pra-Seminar Evaluasi Program Beasiswa Pendidikan untuk Santri Berprestasi di Take's Mansion and Hotel Jakarta tanggal 29 September. 
dari Susenas BPS 2014 menunjukan disparitas yang tinggi dalam pendidikan tinggi antara keluarga mampu dan tidak mampu. Kesempatan keluarga mampu untuk menyekolahkan anaknya ke perguruan tinggi 45,5\% sebaliknyakesempatan keluarga tidak mampu menyekolahkan anaknya ke perguruan tinggi $14,1 \%$. Alasan utama keluarga tidak mampu tidak melanjutkan studi ke pendidikan tinggi karena faktor biaya $34,7 \%$.

Secara regulasi program PBSB ini mendukung program pemerintah dalam pemberian akses kesempatan bagi masyarakat terutama masyarakat tidak mampu, dalam hal ini santri untuk memperoleh pendidikan tinggi. Dalam Petunjuk Teknis PBSB Thun 2016 secara tegas dinyatakan bahwa Program PBSB ditujukan bagi santri yang memiliki prestasi akademik yang baik dan akhlaq yang terpuji dan sangat diutamakan yang berasal dari keluarga kurang mampu".18

Program PBSB bukan berarti tidak diperuntukan bagi siswa mampu. Program ini mengutamakan bagi siswa yang memiliki kemampuan akademik yang tinggi baik keluarga tidak mampu ataupun keluarga mampu meskipun demikian tentu proporsi yang utama adalah diperuntukan bagi santri tidak mampu dengan kemamuan akademik yang baik. Pentingnya kemampuan akademik yang baik akan menjamin bagi santri untuk mampu menyelesaikan studi tepat waktu.

Studi ini menunjukan santri penerima PBSB banyak berasal dari keluarga tidak mampu sehingga tampak adanya relevansi

\footnotetext{
${ }^{18}$ Petunjuk Teknis Pengelolaan Program Beasiswa Santri Berprestasi tahun 2016, h. 33
}

antara implementasi dan tujuan. Dari sisi ini dapat dikatakan bahwa program PBSB telah tepat sasaran. Oleh karena itu konteks kebijakan yang tertuang dalam Petunjuk Teknis PBSB 2016 sudah mendukung kebijakan pemerintah. Sebab, mengakomodasi keluarga tidak mampu untuk memperoleh pendidikan tinggi berarti mengurangi disparitas gap kesempatan memperoleh pendidikan dari kedua strata keluarga tersebut.

Namun demikian jika melihat distribusi pendapatan orang tua santri nampaknya proporsi mereka yang berasal dari keluarga berpenghasilan di atas 2 juta tidak sedikit, yaitu mencapai 49\%. Kata "sangat diutamakan" dalam syarat penerima manfaat PBSB di atas dapat ditafsirkan secara harfiah sebagai proporsi yang lebih banyak untuk keluarga tidak mampu. Oleh karena itu, regulasi PBSB yang sudah tepat mengakomodasi keluarga tidak mampu perlu diiringi dengan sistem pengawasan dalam rekruitmen santri di pesantren. Sederhananya, Kemenag perlu mengatur alokasi atau kuota peserta PBSB yang diajukan oleh setiap pesantren dengan proporsi lebih tinggi bagi santri berasal keluarga tidak mampu.

Adapun aspek alasan mengikuti program PBSB lebih dominan karena memperoleh kesempatan belajar di perguruan tinggi berkualitas (74\% ) dan alasan gratis (58\%) dengan kriteria pemilihan jurusan lebih dominan dilakukan oleh santri 70\% dimana pemilihan tersebut karena alasan faktor minat $75 \%$. Jika PBSB tujuannya adalah pemberdayaan pesantren, maka sudah seharusnya pemilihan studi berdasarkan kebutuhan pesantren. Alasan pemilihan jurusan santri sesuai kebutuhan pesantren 
tercatat rendah $15 \%$ dibandingkan oleh santri sendiri yang mencapai $70 \%$. Selanjutnya jika minat studi didasarkan atas kebutuhan santri, maka tidak mempunyai korelasi positif dengan minat santri untuk memberdayakan pesantren.

Proporsi santri alumni PBSB dengan jurusan umum (teknik, MIPA, Sosial, Kedokteran, Kesehatan, Pertanian) lebih tinggi yaitu mencapai 74,4\% dibandingkan dengan pemilihan jurusan agama (Syariah, Usluhuddin atau ilmu Falak) 25,6\%. Jika dikaitkan dengan tujuan $\mathrm{PBSB}^{19}$ sebagai pemberdayaan sosial bagi pesantren melalui upaya meningkatkan kualitas SDM pondok pesantren di bidang sains, teknologi serta sosial kemasyarakatan, maka sejatinya hasil ini cukup memiliki relevansi. Program PBSB sudah tepat sasaran secara kuantitas proporsi antara jurusan umum dan jurusan agama.

Dimensi kedua dari aspek input adalah efektifitas sosialisasi kebijakan, proses rekruitmendanobjektifitaspenyelenggaraan PBSB. Menurut Sentosa dan Rochana ${ }^{20}$, dua indikator efektifitas sosialisasi kebijakan dapat dilihat dari tersampaikannya kebijakan pada masyarakat dan tingginya partisipasi masyarakat untuk mengikuti kebijakan tersebut. Jika menggunakan dua ukuran indikator ini, maka efektifitas sosialisasi kebijakan PBSB ini "berhasil". Meskipun pihak pesantren menyatakan

\footnotetext{
${ }^{19}$ Petunjuk Teknis Pengelolaan Program Beasiswa Santri Berprestasi tahun 2016, h. 9

${ }^{20}$ Sentosa, A.R, dan Rochana, E, 2010, Efektifitas Sosialisasi Kebijakan Pemerintah Kota Bandar Lampung Tentang Waktu Pembuangan Sampah Sebagai Upaya Menciptakan Kebersihan Lingkungan (Studi pada Kelurahan Sepang Jaya Kota Bandar Lampung), Jurnal Sosiologi, Vol. 14, No. 1: h. 1-9
}

pernah mengikuti sosialisasi (46\%), akan tetapi bentuk sosialisasi seperti surat edaran sangat efektif (77\%). Terlebih sistem pendaftaran santri PBSB sudah berbasis online yang dapat menjangkau seluruh area wilayah Indonesia.

Hal yang paling signifikan adalah tingkat partisipasi santri mengikuti program seleksi PBSB meningkat 31\% dari tahun 2014 ke tahun 2015 dimana tahun 2014 tercatat ada 3324 santri yang mengikuti seleksi PBSB dan meningkat menjadi 4359 santri pada tahun 2015. Hal ini juga didorong oleh persepsi Kyai atas sistem rekruitmen PBSB yang menyatakan mudah 55\%, sebaliknya 45\% menyatakan kurang mudah dan sulit. Pesantren nampaknya masih butuh waktu penyesuaian dengan sistem rekruitmen online atau pendaftaran melalui website. Hal ini dikarenakan perluasan jaringan internet masih belum merata antar wilayah, terutama bagi kawasan pesantren yang belum sepenuhnya mengakses internet atau pesantren dengan jaringan internet yang kurang lancar.

Selanjutnya tingkat kepuasan Kyai atas objektifitas penyelenggaraan PBSB mencapai $56 \%$. Hal ini dikarenakan tidak adanya intervensi Kemenag tentang kelulusan calon penerima beasiswa PBSB. Namun, terdapat ketidakpuasan Kyai karena faktor ketidakmerataan santri yang memperoleh PBSB antar pesantren. Ada pesantren yang setiap tahun, santrinya "selalu" memperoleh beasiswa PBSB, di sisi lain, ada pesantren yang "terkadang" mendapat atau tidak mendapat beasiswa PBSB, khususnya pesantren yang menyelenggarakan pendidikan mu'adalah/salafiyah. Ada pesantren yang jumlah alumni PBSB cukup banyak, di sisi lainnya ada pesantren yang 
jumlah alumni PBSB hanya 1-2 alumni. Ini artinya ada disparistas alumni PBSB antar pesantren yang mendapatkan beasiswa PBSB.

Berdasarkan pada uraian di atas, keberhasilan aspek input nampak jelas. Pertama, relevansi kebijakan Kementerian Agama untuk memberikan akses pendidikan beasiswa bagi keluarga tidak mampu di mana pada tataran implementasi sudah mengakomodasisantridengankeluargatidak mampu, meskipun proporsi mereka yang berasal dari keluarga dengan pendapatan lebih dari 2 juta masih cukup tinggi. Kedua, pilihan studi pada pendidikan umum yang notabene dekat dengan penerapan sain dan teknologi seperti MIPA, Teknik, Pertanian, Kedokteran, Kesehatan Masyarakat, Ilmu Sosial mempunyai proporsi yang lebih tinggi dari pilihan studi agama (syariah, ilmu falak dan usluhuddin). Ini menunjukan ada relevansi antara implementasi dengan tujuan PBSB secara kuantitas. Ketiga, adanya efektifitas sosialisasi kebijakan program PBSB di mana terjadi peningkatan yang signifikan (31\%) santri yang mendaftar dari tahun 2014 ke tahun 2015. Keempat, sistem pendaftaran PBSB berbasis online mampu menjangkau lebih luas wilayah Indonesia. ${ }^{21}$

\footnotetext{
${ }^{21}$ Catatan kritis pada aspek input yaitu; pertama, pemilihan jurusan atas dasar kebutuhan pesantren masih 15\%, di mana lebih tinggi pemilihan jurusan atas dasar minat santri (70\%); kedua, proporsi Kyai yang mempersepsikan objektifitas dan tingkat kepuasan penyelenggaraan PBSB terhitung "sedang", yakni 55\%; ketiga, sosialisasi atau transparansi publik atas proses rekruitmen PBSB yang bebas intervensi panitia penyelenggaran PBSB (Kementerian Agama) dan bebas nepotisme (kedekatan hubungan); keempat, kurangnya proporsi mu'adalah yang mendapatkan afirmasi mendapatkan beasiswa PBSB; dan kelima, pembatasan/pengurangan "kuota" santri bagi
}

\section{Tingkat Relevansi Proses Pendidikan}

Komponen proses adalah sesuatu yang berhubungan dengan prosedur kegiatan implementasi kebijakan atau keputusan yang meliputi lama studi santri, aktivitas pembinaan santri PBSB, evaluasi PBSB serta mengidentifikasi masalah dan kendala selama proses studi.

Studi ini menemukan bahwa lama studi santri umumnya antara 4-5 tahun mencapai $64,1 \%$ dan yang menyelesaikan studi kurang dari 4 tahun mencapai 26,5\%. Ini berarti tingkat keberhasilan santri untuk menyelesaikan pendidikan tepat waktu sangat tinggi terlebih ada santri PBSB yang mempunyai kemampuan untuk menyelesaikan pendidikan tinggi kurang dari 4 tahun.

Jika dikaitkan asal santri dari MA/ Mua'dalah dengan jurusan pilihan studi di perguruan tinggi, maka kemampuan santri untuk lulus dari perguruan tinggi berciri khas agama berbeda dengan jurusan umum. Santri dengan pilihan studi agama lulus kurang dari 4 tahun mencapai 57\%, sedangkan santri dengan pilihan pendidikan umum mencapai $16 \%$. Sebaliknya, bagi santri yang lulus antara 4-5 tahun untuk pemilihan jurusan agama sebesar $42 \%$ dan jurusan umum lebih tinggi mencapai 72\%. Artinya santri yang lulus kurang dari 4 tahun lebih tinggi untuk mereka yang memilih jurusan agama dibandingkan jurusan umum.

Hal yang cukup menarik untuk kajian dalam aspek proses ini adalah mengaitkan antara lama studi santri dengan latar belakang ekonomi orang tua santri. Secara

pesantren yang sudah banyak menerima beasiswa PBSB. 
umum, studi ini menunjukan bahwa untuk setiap kelompok pendapatan orang tua mempunyai kemungkinan lulus antara 4-5 tahun. Akan tetapi, jika dilihat faktor keberhasilan lebih jauh, yaitu bagi mereka yanglulus kurang dari 4 tahun, maka proporsi santri dari keluarga dengan pendapatan kurang dari 2 juta lebih tinggi dari kelompok lainnya. Studi ini menunjukan proporsi santri untuk lulus kurang dari 4 tahun lebih tinggi untuk kelompok pendapatan orang tua "kurang dari 2 juta," yaitu mencapai 32\% dibandingkan kelompok penghasilan orang tua lainnya. Di sisi lain, santri dengan ekonomi keluarga lebih dari 6 juta untuk lulus kurang dari 4 tahun lebih rendah, yaitu 13\%. Tren yang sama jika dikaitkan dengan latar belakang pendidikan orang tua ${ }^{22}$.

Pentingnya analisis ini bila mengaitkan antara kebijakan PBSB dengan keluarga tidak mampu. Jika proporsi keluarga tidak mampu didekati oleh latar belakang ekonomi orang tua dan pendidikan orang tua, maka sudah sangat tepat kebijakan PBSB ini yang mengalokasikan pemberian beasiswa lebih tinggi bagi keluarga tidak mampu. Hasil ini membuktikan bahwa jika santri dari keluarga tidak mampu diberikan kesempatan untuk memperoleh pendidikan tinggi, maka tingkat keberhasilan mereka menempuh pendidikan tinggi dapat sama atau jauh lebih baik.

Dimensi kedua dari aspek proses adalah mengetahui hambatan atau kendala

${ }^{22}$ Hasil analisis cross tabulasi antara latar pendidikan orang tua dengan lama studi. Dari 58 santri dengan pendidikan orang tua SD/MI, proporsi untuk lulus dibawah 4 tahun 37,9\%, dari 37 latar belakang pendidikan orang tua SMP/MTs untuk lulus dibawah 4 tahun $(36,7 \%)$ dan dari 61 santri dengan latar belakang pendidikan orang tua sarjana untuk lulus dibawah 4 tahun lebih rendah ada $21 \%$ yang dialami oleh santri. Dari 11 (sebelas) indikator kendala yang ditanyakan kepada santri, hambatan yang paling utama adalah "dana bantuan PBSB telat cair". Dari 234 santri, mayoritas (56\%) yang menyuarakan keterlambatan bantuan PBSB. Padahal, ini sangat berpengaruh kepada santri, terutama untuk memenuhi biaya sehari-hari (living cost) dan juga keperluan buku. Mereka yang terpengaruh kondisi ini adalah santri PBSB yang berasal dari keluarga dengan pendapatan rendah. Dari 131 santri alumni PBSB yang menyatakan "dana bantuan PBSB telat cair", ada 64 orang atau (49\%) dari mereka dengan latar belakang keluarga penghasilan kurang dari 2 juta. Hasil studi ini menginformaikan bahwa mereka yang berasal dari orang tua dengan pendapatan rendah "terganggu" dengan kondisi ini di mana pada umumnya mereka berharap dana beasiswa ini.

Aspek kedua dan ketiga yang disuarakan santri PBSB adalah kurangnya pembinaan dari pihak Kemenag dan Perguruan Tinggi yang dinyatakan masing-masing oleh 20.1\% dan $18.4 \%$ santri. Pihak Kemenag sebenarnya telah melakukan program pembinaan dengan memberikan motivasi kepada santri untuk studi tepat waktu, materi wawasan kepesantrenan atau wawasan kepemimpinan. Namun, suara kurangnya pembinaan masih dirasakan manakala santri mengalami kesulitan dalam mengaplikasikan apa yang diperoleh diperguruan tinggi dengan relialitas di pesantren. Misalnya, sulitnya jurusan perkapalan yang dipelajari di perguruan tinggi yang tidak relevan dengan kebutuhan pesantren. Begitu pula jurusan teknologi informasi yang dipelajari di perguruan tinggi tidak bisa diimplementasikan manakala 
tidak ada ketersediaan peralatan yang mendukung di pesantren. Jurusan budidaya pertanian sulit diterapkan manakala di pesantren tidak tersedia lahan pertanian.

Berdasarkan uraian di atas, keberhasilan aspek proses nampak terlihat pada; pertama, penyelesaian studi santri yang tepat waktu. Bahkan, ada banyak santri yang lulus kurang dari 4 tahun; kedua, meskipun santri berasal dari keluarga tidak mampu, tetapi tidak menghambat mereka untuk berprestasi. Lama studi kelompok ini relatif lebih baik dibandingkan santri dengan latar belakang keluarga penghasilan di atas 2 juta. Meskipun demikian, keterlambatan dana bantuan PBSB (living cost) dan konsep pembinaan masih menjadi kendala serius.

\section{Tingkat Relevansi Output Pendidikan}

Komponen produk atau output program PBSB adalah sesuatu yang berhubungan dengan keberhasilan pencapaian tujuan PBSB, yang meliputi prestasi, sebaran alumni, pendayagunaan alumni dan faktor penentu keberhasilan pemberdayaan pesantren. Berikut hasil pengolahan data.

Aspek prestasi penerima beasiswa PBSB dapat dilihat dari tabel berikut ini.

Table 2. Nilai Rata-Rata IPK Santri Alumni PBSB (Berdasarkan Perguruan Tinggi)

\begin{tabular}{lccc}
\hline \multicolumn{1}{c}{ Perguruan Tinggi } & N & Rerata & Standard Deviasi \\
\hline IPB & 53 & 3.15 & 0.40 \\
\hline ITB & 1 & 3.05 &.- \\
\hline ITS & 36 & 3.25 & 0.27 \\
\hline STAINU & 5 & 3.43 & 0.32 \\
\hline UGM & 25 & 3.32 & 0.23 \\
\hline UIN Malang & 6 & 3.70 & 0.12 \\
\hline UIN Sunan Ampel & 19 & 3.61 & 0.14 \\
\hline UIN Sunan Kalijaga & 16 & 3.71 & 0.17 \\
\hline UIN Syarif Hidayatullah & 25 & 3.31 & 0.21 \\
\hline UIN Wali Songo & 19 & 3.60 & 0.22 \\
\hline UNAIR & 25 & 3.28 & 0.28 \\
\hline UPI & 4 & 3.35 & 0.26 \\
\hline Total & 234 & 3.35 & 0.33 \\
\hline
\end{tabular}

Sumber: Data pengolahan 2016, Puslitbang Pendidikan Agama dan Keagamaan
Nilai rerata santri alumni PBSB sangat membanggakan, yaitu 3,35 dengan sebaran merata di perguruan tinggi umum atau berciri khas agama. Bila dilihat dari asal perguruan tinggi, nampaknya rerata IPK santri yang lulus dari perguruan tinggi umum tidak jauh berbeda dengan mereka yang lulus dari pendidikan tinggi agama. Hasil ini memberikan gambaran bahwa santri yang berlatar belakang pendidikan Madrasah Aliyah atau Mu'adalah mampu bersaing, terlebih untuk mereka yang mengambil studi di perguruan tinggi umum. Namun, masih ada santri alumni PBSB yang mempunyai IPK dibawah 3,0 (11,1\%). Pembinaan santri oleh Kemenag dan Perguruan Tinggi selama santri studi nampaknya berbuah hasil jika dilihat dari rerata IPK ini. Selain IPK yang memuaskan, santri juga dapat lulus tepat waktu.

Jika hasil IPK ini dilihat berdasarkan latar belakang sosio-ekonomi keluarga, yaitu proksi pendapatan orang tua, maka nilai rata-rata IPK santri dengan latar belakang pendapatan orang tua di bawah 2 juta juga cukup membanggakan yaitu rerata IPK 3,32. Hasil ini menguatkan dugaan bahwa investasi pendidikan dengan menyekolahkan santri keluarga tidak mampu akan menumbuhkan kesadaran mereka untuk berjuang dan berhasil dalam pendidikan.

Dimensi ketiga aspek produk adalah tempat pengabdian dan lama pengabdian. Dalam Petunjuk Teknis PBSB 2016 secarajelas disebutkan bahwa santri wajib mengabdi setelah lulus. ${ }^{23}$ Secara keseluruhan, sebanyak $89,7 \%$ santri menyatakan mengabdi setelah

\footnotetext{
${ }^{23}$ Petunjuk Teknis Pengelolaan Program Beasiswa Santri Berprestasi tahun 2016, h. 9
} 
studi di pesantren asal, 2,6\% mengabdi di pesantren yang direkomendasikan oleh Direktorat Pontren, 2,1\% mengabdi di pesantren yang di rekomendasikan oleh pesantren asal dan sisanya ada 5,6\% yang menyatakan tidak mengabdi. Persentase santri yang mengabdi sebanyak 95,4\% menunjukan tingkat kepatuhan santri pada regulasi. Bagi santri PBSB yang tidak mengabdi di pesantren asal lebih dikarenakan belum tersedianya fasilitas yang memadai yang ada di pesantren asal untuk pengabdian, seperti santri alumni jurusan kedokteran/ilmu kesehatan yang menyatakan bahwa tidak adanya klinik di pesantren asal sehingga diarahkan untuk mengabdi di pesantren lainnya. Sementara dilihat dari sisi pengabdian terlihat pada grafik berikut:

Grafik 1. Lama Pengabdian

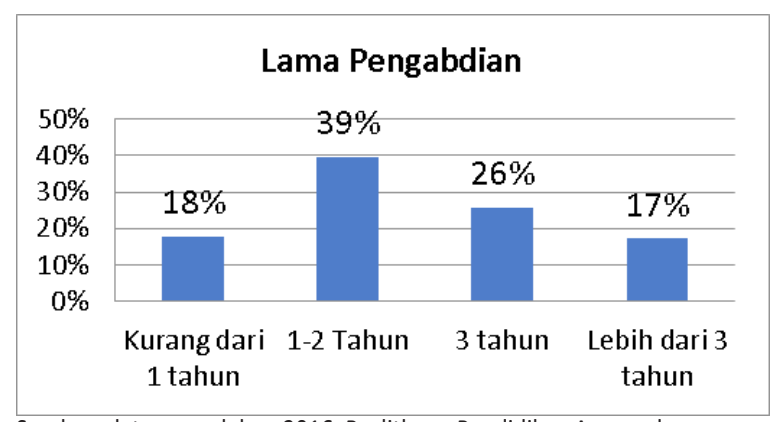

Sumber: data pengolahan 2016, Puslitbang Pendidikan Agama dan Keagamaan

Pada grafik tersebut menunjukan ada $18 \%$ santri yang mengabdi di pesantren kurang dari 1 tahun dan 39\% santri yang mengabdi antara 1 hingga 2 tahun. Artinya bila dikaitkan dengan kewajiban santri yang tertuang dalam Petunjuk Teknis 2016 bahwa santri wajib mengabdi selama 3 tahun, nampaknya regulasi ini sepenuhnya belum ditaati oleh santri. Meskipun 95,4\% santri mengabdi di pesantren, akan tetapi studi ini menemukan 57\% santri tidak melanjutkan pengabdian hingga penuh 3 (tiga) tahun. Praktis, santri yang mematuhi kewajiban pengabdian selama 3 (tiga tahun) sebesar $43 \%$ atau ada $17 \%$ santri tetap mengabdi di pesantren hingga lebih dari 3 tahun.

Aktifitas alumni PBSB selama pengabdian dapat dilihat dari tabel berikut:

Table 3. Aktifitas Selama Pengabdian

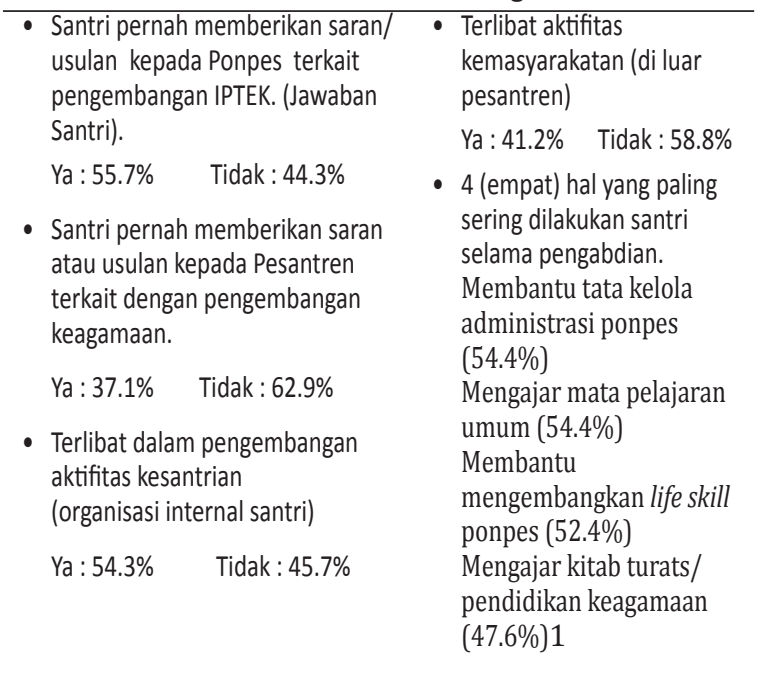

Sumber: Data pengolahan 2016, Puslitbang Pendidikan Agama dan Keagamaan

Santri tidak hanya pandai secara akademis (IPK yang tinggi) akan tetapi didorong berperan sebagai "agent of change" - kaum perubah. Tabel di atas menunjukkan frekuensi memberikan usulan, saran perbaikan, keterlibatan dalam aktifitas kesantrian atau kemasyarakat masih belum memuaskan dengan proporsi menjawab "ya" sekitar 50\% atau kurang dari 50\%.

Bila dilihat dari jenis aktifitas, alumni PBSB pada pengabdian umumnya terlibat dalam adminsitrasi pesantren, mengajar dan mengembangkan life skill atau memotivasi santri pesantren. Berikut adalah suara santri terkait usul, saran, aktifitas selama pengabdian.

"Melakukanpelatihankomputer,pengembangan website pondok pesantren, pelatihan jurnalistik, 
mengadakan praktikum, seminar kesehatan, digitalisasi perpustakaan, pengembangan klinik pesantren, pembuatan sistem pusat informasi, pembinaan elektronika, konseling pesantren, pengembangan life skill (santri wirausaha, cara pembelajaran keagamaan modern), menambah fasilitas labolatorium, pengadaan tes akademik, pengadaan klub sains, pelatihan budaya tanaman, mengadakan lesprivat, pengadaan wifi pesantren, penambahan komputer, pengadaan teleskop, pelatihan internet, absen fingerprint, adanya klub biologi, penertiban majalah, menghitung arah kiblat, pengajaran bahasa inggris, pembinaan ruhiyah dan pengembangan tahsin dan tahfidz al-Quran, pendisiplinan shalat, perbanyak kajian kitab, pembinaan jamiyatul muballiqin, pengajaran ilmu falak, pengembangan kurikulum madrasah, pembinaan ilmu balaghoh, mengadakan daurah ramadhan dan pembinaan kitab kuning, membuat klub bahasa inggris, koordinator keamanan, mengadakan pelatihan tambahan belajar (bimbingan belajar), pembina koperasi..."

Selama proses pengabdian, alumni PBSB sebenarnya tidak mengalami hambatan dalam hal komunikasi dan interaksi dengan pimpinan pondok pesantren. Terbukti 79,6\% santri menyatakan bahwa mereka selalu berkomunikasi dengan Kyai/ Ustadz di pesantren dan 68,3\% santri alumni PBSB menyatakan ada perhatian dari pesantren walaupun kesempatan diberikan memberikan usulan dinyatakan oleh 54,8\%. Proses komunikasi merupakan ukuran yang akan mengantarkan keberhasilan pemberdayaan alumni PBSB di pesantren tempat mengabdi. Proses komunikasi tersebut diawali dari adanya interkasi yang intensif antara alumni PBSB yang mengabdi dengan para Kyai dan ustadz/ pengajar. Melalui proses komunikasi maka proses transmisi keilmuan yang diperoleh santri selama studi di perguruan tinggi dapat diberikan kepada santri lainnya yang ada di pesantren

Keberhasilan aspek output/ produk nampak pada; pertama, prestasi akademik santri alumni PBSB yang membanggakan dengan rerata IPK 3,35. Bahkan, tercatat rerata santri alumni PBSB yang berasal dari keluarga tidak mampu juga cukup tinggi 3,32; kedua, alumni PBSB yang mengabdi di pesantren. Namun demikian, masih banyak santri yang mengabdi kurang dari 3 tahun. Ini membuktikan bahwa santri belum sepenuhnya mentaati regulasi pengabdian. Begitupula, peran santrisebagai pemberdaya pesantren belum sepenuhnya tumbuh. Tingkat kreatifitas, usulan perbaikan pesantren, aktif dalam kelembagaan pesantren atau masyarakat masih tergolong rendah. Mereka melakukan pengabdian terbatas pada pengelolaan administrasi, pengajaran dan pengembangan life skill (motivasi santri).

\section{Tingkat Relevansi Outcome Pendidikan}

Komponen outcome adalah sesuatu dampak atau manfaat alumni PBSB terhadap penguatan kelembagaan pesantren. Indikator yang digunakan dalam melihat outcome adalah indikator tujuan PBSB. Keberhasilan program PBSB dalam Petunjuk Teknis PBSB 2016 tertuang dalam 4 (empat) indikator yaitu: a) kesiapan santri memberdayakan pesantren; b) peningkatan kualitas SDM pesantren dengan menebarkan ilmubagi ustadz/santri lainnya di pesantren; c) transfer dan penerapan ilmu pengetahuan sain dan teknologi di pesantren; dan d) peningkatan kualitas pendidikan dan pengajaran. 
Ukuran outcome atau dampak yang dirasakan pesantren sebenarnya tidak secara langsung dapat diukur dalam jangka pendek karena dampak dapat diukur dalam jangka panjang. Outcome atau dampak dapat diawali terkait bagaimana sebenarnya Kyai mempersepsikan program PBSB ini. Pada bagian ini ada beberapa hal yang bisa dilihat yaitu: tingkat kebermanfatan, dimana kyai menjawab sangat bermanfaat $67 \%$, bermanfaat $24 \%$ dan cukup bermanfaat 9\%. Persepsi yang dirasakan Kyai terhadap program PBSB ini sangat baik dimana PBSB memiliki kemanfaatan terhadap pesantren (91\%), bagi santri (100\%) dan masyarakat 90\%). Artinya Kyai mempunyai sikap sangat positif terhadap program PBSB.

Adapun perubahan/kemajuan positif yang dialami pesantren selama pembinaan dijawab 78,7\% santri menyatakan bahwa selama proses pengabdian di pesantren memberikan dampak positif bagi pesantren, sedangkan $21,3 \%$ santri menyatakan belum berkontribusi penting bagi pesantren selama pengabdian. Ada beberapa faktor yang dapat menjelaskan berkontribusi atau tidaknya santri terhadap pesantren. Di antaranya adalah adanya kesempatan yang diberikan oleh pesantren kepada santri alumni PBSB untuk memberikan masukan perbaikan, adanya perhatian dari pihak pesantren kepada alumni PBSB, mudahnya komunikasi dengan pihak pengelola pesantren (Kyai dan ustadz), keterlibatan dalam aktifitas keputusan rapat, dan keterlibatan dalam aktifitas mengajar.

Dari aspek perilaku santri alumni PBSB selama pengabdian, secara keseluruhan Kyai menilai bahwa santri mempunyai akhlak, pengetahuan keislaman, ibadah dan wawasan toleransi yang baik, yaitu berada pada skor di atas $80 \%$ sampai $90 \%$. Ini menunjukan bahwa santri selama pengabdian di pesantren berperilaku baik dan toleran.

\section{PENUTUP}

Impelementasi PBSB dalam satu dekade lebih program ini telah memberikan kontribusi terhadap penguatan pesantren melalui kebijakan afirmatif untuk mengembangkan dan menggerakan potensi pesantren, walaupun kontribusi ini masih terbatas. Hal ini tercermin dalam kebijakan Kementerian Agama yang memberikan akses pendidikan beasiswa bagi keluarga tidak mampu di kalangan pesantren. Mobilitas pendidikan yang diraih oleh santri pesantren telah meningkatkan kapasitas keahlian akdemik mereka yang semakin meluas dengan pilihan studi pada pendidikan umum (sain dan teknologi), seperti MIPA, Teknik, Pertanian, Kedokteran, Kesehatan Masyarakat, dan Ilmu Sosial. Dengan kata lain, santri PBSB tidak saja menguasai studi agama (syariah, ilmu falak dan usluhuddin), tetapi juga sains dan teknologi. Kenyataan ini menunjukan bahwa pesantren telah memiliki modal sosial dan modal intelektual untuk mengembangkan dan memperkuat kelembagaan pesantren. Kebijakan afirmatif ini ternyata berhasil mengantarkan santri yang berasal dari keluarga tidak mampu untuk berprestasi yang dibuktikan dengan lama studi mereka di Perguruan Tinggi yang tepat waktu dengan indeks prestasi yang memuaskan. Sayangnya, optimalisasi pemberdayaan santri di pesantren tidak berhasil dengan di mana tingkat pengabdian mereka selama di pesantren setelah lulus kuliah belum sesuai dengan 
bidang keilmuan mereka. Bahkan, tingkat kreatifitas, usulan perbaikan pesantren, aktif dalam kelembagaan pesantren atau masyarakat masih tergolong rendah, yang pada umumnya terbatas pada pengelolaan administrasi, pengajaran dan pengembangan life skill (motivasi santri). Namun demikian, program PBSB ini memiliki tingkat kebermanfaatan yang kuat bagi santri untuk menggerakan mobilitas intelektual dan bagi pesantren untuk menggerakan pemberdayaan pesantren.

\section{UCAPAN TERIMAKASIH}

Sukur alhamdulillah artikel berjudul Evaluasi Program Bantuan Beasiswa Santri Berprestasi (PBSB) di Pesantren dapat diselesaikan, karena itu penulis menyampaikan terima kasih dan penghargaan yang setinggi-tingginya kepada berbagai pihak:, yaitu, kepada para peneliti (Utama, Madya dan Muda), kepada Dr.Amin Haedari, MPd dan Prof. Dr.Arif Sumantri, M.A sebagai narasumber Seminar yang telah memberikan saran dan masukan baik substansi maupun teknis penulisan. Demikian juga kepada Dr. Jayadi, M.A (Kasubdit di lingkungan Direktorat Pendidikan Diniyah dan Pesantren) yang telah memberikan data dan informasi terkait penyelenggaraan Program Bantuan Beasiswa Santri Berprestasi (PBSB) di Pesantren dan khususnya kepada para Kasi Kementerian Agama Kabupaten/Kota, Pimpinan pondok pesantren dan alumni PBSB di berbagai daerah (DKI Jakarta, Jawa Tengah, Jawa Timur, Jawa Barat, Yogyakarta dan Banten) yang telah bersedia memberikan informasi dan mengisi kuesioner ketika penelitian dilaksanakan. Semoga amal baik bapak/ibu/
Saudara dijadikan amal saleh oleh Allah Swt dan mendapat pahala yang berlipat ganda. Amiin.

\section{DAFTAR PUSTAKA}

Bappenas, (2016): Peningkatan Akses Pendidikan Tinggi Melalui ProgramProgram Afirmasi.

Catatan Bank Dunia, (2011): Sumber: http:// www. worldbank. org/in/news/pressrelease/2011/10/13/higher-educationcontribute-even-more-indonesiadevelopment.

Direktorat PD Pontren Kementerian Agama tahun, (2014): "Dokumen Data Hasil Apdat".

Direktorat PD. Pontren dan Ditjen Pendidikan Islam, Kementerian Agama RI. (2015): Petunjuk Teknis Pengelolaan Program Beasiswa Santri Berprestasi (PBSB).

Direktorat Pendidikan dan Agama Kementerian PPN/ BAPPENAS, (2016): Disampaikan dalam Pra-Seminar Evaluasi Program Bantuan Beasiswa Santri Berprestasi di Take's Mansion and Hotel Jakarta, 29 September

Green \& Haines, (2002): dalam Asset Building and Community Development, pengembangan model pemberdayaan $A B C D$ melihat menguraikan Physical Capital, Finansial Capital, Environmental Capital, Technological Capital, Human Capital, Social Capital dan Spiritual Capital..

Jaedun, Amat, (2010): Metode Penelitian Evaluasi Program, Makalah Disampaikan Pada Kegiatan Pelatihan Metode Penelitian Evaluasi Kebijakan dan Evaluasi Program Pendidikan

Leonard Rutman, (1984): Evaluation Research Methodology,New Delhi, Sege Publication India PVT. Ltd, 2 ed W. James Popham, 
(1981), Modern Educational Evaluation, New Jersey: Prenctice Hall Inc.

Mazen Hashem, (2006): "Contemporary Islamic Activism: The Shades of Praxis" dalam Sociology of Religion, Vol. 67, No. 1 (Spring,).

Ömer Ta, (2009): dalam "Fighting Radicalism, not 'Terrorism': Root Causes of an International Actor Redefined" dalam SAIS Review Vol. XXIX No. 2, (SummerFall).

Quintan Wiktorowicz dan Karl Kaltenthaler, (2006): dalam "Rationality of Radical Islam Political" dalam Science Quarterly, Vol. 121, No. 2, (Summer,).

Renstra Diektorat Dirjen Pendidikan Islam Kementerian Agama RI tahun 2015-2019
Sentosa, A.R., dan Rochana, E, (2010): Efektifitas Sosialisasi Kebijakan Pemerintah Kota Bandar Lampung Tentang Waktu Pembuangan Sampah Sebagai Upaya Menciptakan Kebersihan Lingkungan (Studi pada Kelurahan Sepang Jaya Kota Bandar Lampung), Jurnal Sosiologi, Vol. 14, No. 1: 1-9

Taufik M Tata, (2016): PBSB dari Masa ke Masa, Makalah disampaikan dalam Pra Seminar Evaluasi Program Beasiswa Santri Berprestasi, di Take's Mansion Hotel Jakarta, 29 September.

W. James, Popham, 1981: Modern Educational Evaluation, New Jersey: Prenctice Hall Inc. 